\title{
Adult Mortality Differentials and Regional Development at the local level in Brazil, 1980-2010
}

\author{
Bernardo Lanza Queiroz \\ Universidade Federal de Minas Gerais \\ lanza@cedeplar.ufmg.br \\ Everton E. Campos de Lima \\ Unicamp \\ everton@nepo.unicamp.br \\ Flávio Freire \\ Universidade Federal do Rio Grande do Norte \\ fhfreire@ccet.ufrn.br \\ Marcos Gonzaga \\ Universidade Federal do Rio Grande do Norte \\ mrcs.roberto@gmail.com
}

\begin{abstract}
In this paper, we study study spatial and temporal adult mortality trends in small areas of Brazil, from 1980 to 2010, and its relation to socioeconomic and public health developments. Brazil is marked by huge regional and social inequality and it is important to understand how it could be related to trends and differences in adult mortality. There are several studies about trends in infant and child mortality, but much less is known about adult mortality. We are also interested in understand whether there is a convergence or divergence in adult mortality. This is relevant because changes in life expectancy in the near future could be heavily explained by differences in adult mortality as infant and child mortality have shown signs of convergence in recent years
\end{abstract}

\author{
Preliminary draft \\ Please, do not cite without authors permission \\ Comments are welcome
}




\section{Background}

Brazil is marked by huge regional and social inequality and it is important to understand how it could be related to trends and differences in adult mortality. There are several studies about trends in infant and child mortality, but much less is known about adult mortality. We are also interested in understand whether there is a convergence or divergence in adult mortality. This is relevant because changes in life expectancy in the near future could be heavily explained by differences in adult mortality as infant and child mortality have shown signs of convergence in recent years

\section{Objective}

We study study spatial and temporal adult mortality trends in small areas of Brazil, from 1980 to 2010, and its relation to socioeconomic and public health developments

\section{Methods}

We make use of the Ministry of Health database, DATASUS (http://www2.datasus.gov.br) and small-area adult mortality estimates produced by Queiroz, Freire, Lima and Gonzaga (2016). We use spatial analysis to observe trends and concentration of adult mortality in the country and relation to socio-economic factors and public health measures. In the second step we use spatial regression techniques to evaluate changes in adult mortality to changes in the variables of interest.

\section{Results}

We find increasing percentage in the share of young adult population is related to an increase in 45q15 for both males and females. We also find that, for females, decrease in unemployment rates from 1980/1991 to 2000/2010 is related to an increase in the 45q15. This is an unexpected result and more analyses need to be performed in order to understand this association. Gini Index, a measure of income inequality, has also an impact on the observed changes in 45q15, but only among males. More intriguing, the relationship has change signal during the period of analysis, indicating that improvements in income distribution (decline in gini) are associated with more deaths between ages 15 to 60 years

\section{Conclusion}

We find a significant concentration of adult mortality levels of the country. We also observed that the difference between males and females mortality stayed high and stable over time. We observe that contrary to common beliefs the reduction in income inequality in the country is not related to a reduction in adult mortality levels.

\section{Contribution}

We investigate spatial and temporal trends in adult mortality (45q15) in a country marked by huge socio-economic regional differences. We relate changes in adult mortality to socioeconomic changes

Keyworkds: mortality differentials, Brazil, small-area estimation, spatial analysis 


\section{Introduction}

In recent decades, most countries in Latin America, and Brazil, experienced an accelerated decline in infant, child and adult mortality. The average gain in life expectancy at birth between 1950 and 2010 was about 15 years, a much faster process than what happened in developed countries. In 1950, life expectancy at birth in the region was around 51 years, reaching 67 years in 1990 and over 70 years in 2010. However, the rates observed around 2000 in several Latin American countries were similar to the rates observed in the USA and Canada in the 1950s (Palloni and Pinto, 2011), thus, showing that there are still room for improvements in terms of life expectancy in the region. In addition to that, there is a wide variation of mortality levels and life expectancy across and within countries in Latin America.

Brazil has follow a similar path, there are signs of convergence in infant mortality across regions in Brazil, as infectious diseases reduced its death toll, but there are still large differentials in life expectancy at birth and adult mortality levels across Brazilian regions. We argue that large and persistent levels of income and regional inequality play an important role in observed differences in mortality levels across socioeconomic groups and regions of a country (Fenelon, 2013; Wilmoth et. Al, 2011, Bafuri, et.al, 2012). In the case of Brasil and other LAC countries, there is a large body of literature on infant and child mortality as compared to adult mortality. In addition, the knowledge of regional differential infant mortality in Brazil is much broader than the adult or overall mortality (Sousa, Hill and Dal Poz, 2010; Aquino, Oliveira and Barreto, 2009; Sabindran, Khan and Timmins, 2008 Sastry, 2004a, 2004b, etc.). Regardless of this, studies that sought to obtain adult mortality and life expectancy at birth estimates for Brazilian municipalities (Horta, et.al, 1998) usually are based on model life tables, constructed from the infant mortality information, rather than trying to produce adult mortality estimates by using the available information, or by analyzing in detail the quality of the data and the evolution of mortality in the region.

There is an extensive literature on estimates and analysis of mortality data in different Latin America countries (Duarte, et.al, 2005; Paes, 2005; Agostinho and Queiroz, 2010; Rodriguez-Garcia, 2007; Composterga-Cruz , 1989; Piscoya-Diaz and Queiroz, 2010; Vega, et.al, 2006; among others), but, all focus on more aggregate analyses (at states and/or provinces levels) and only at one point in time, i.e. From our knowledge there are 
not many studies on the mortality differentials for smaller units of analysis in Brazil nor Latin America.

We argue that in the case of Brazil, life expectancy (summary measure of health condition and important indicator for development of health policies) trends are becoming more determined by variability in adult mortality, since infant an child mortality are converging to lower levels. There are some examples of studies in this line for developed countries (Fenelon, 2013; Ezzati, et.al, 2008; Kulkarni, et.al, 2011; Rees and Brown, 2006; Valkonen, 1992), but few studies for developing countries (Ahmed and Hill, 2011; Justin, et.al, 2012 and Queiroz, et.al, 2012; Lima and Queiroz, 2014; Queiroz, et.al, 2016). Lima and Queiroz (2014) and Queiroz et al. (2016) produced estimates of completeness of death counts coverage and adult mortality estimates in more disaggregated geographical levels ${ }^{1}$, using a combination of Death Distribution Methods (DDM) and Empirical Bayesian statistics. In this paper, we use the mortality estimates produced by the research group (available at Lima and Queiroz, 2014; Queiroz et al., 2016) to provide a more substantive analysis on regional mortality differentials in Brazil.

We study spatial and temporal adult mortality trends in 137 small areas of Brazil, from 1980 to 2010, and its relation to socioeconomic and public health developments. Brazil is marked by huge regional and social inequality, and there is large variation in the quality and supply of public policies in health and education. Therefore, it is important to understand how these elements could be related to the past 30 years of adult mortality development. In particular, we study the impact on adult mortality (measure by 45q15) of economic factors, social factors, health infrastructure and, as well as, living conditions.

Due to Brazil geographical dimensions, we believe that there is huge spatial heterogeneity concerning 45q15 evolution and differentials. Also, socioeconomic inequality and development levels might are related to differences and trends in adult mortality across regions of the countries. It is important to incorporate a spatial model to our analyses, which allows us to consider the possibility that spatial auto-correlation my affect our results and, in this sense, we also control for the presence of unseen spillover neighborhood effects on adult mortality. The spatial trend is important because we are also interested in understanding whether there is a convergence or divergence in adult

\footnotetext{
${ }^{1}$ The estimates produced in both studies concern mesoregions, which are small areas formed by aggregation of municipalities.
} 
mortality throughout time. This study is relevant because changes in life expectancy in the near future could be heavily explained by differences in adult mortality, as infant and child mortality have shown signs of convergence in recent years.

\section{Latin America experiences in mortality decline}

There are a number of important studies evaluating the transition from mortality in Latin America and for specific countries (Timaeus, Chackiel and Ruzicka, 1996). Arriaga and Davis (1969) pioneered the studies on mortality in the region and, according to them, socioeconomic differentials across countries play a role to explain mortality variations until 1930s. After this period, we saw a convergence in life expectancy that occurred independent of the levels of economic development. They emphasize the role of public health measures such as new technology on medicine and vaccines, imported by developing countries from more developed parts of the world (Arriaga and Davis, 1969).

Preston (1976) analyzes the effect of private income on mortality decline by decomposing worldwide life expectancy from 1930s to 1960s. In the case of less developed countries, he also argues that despite private incomes have been influential in determining national levels of life expectancy at a moment in time, it does not imply that changes in private incomes have been the dominant factor in mortality changes during the twentieth century (Preston, 1980). In fact, the actual changes in income may have been too small to account for the observed mortality changes (Preston, 1976, 1980).

Palloni (1990) shows that the decline of overall mortality happened in a lesser pace as compared to most Western European countries. However, mortality decline under the age of one year was an exception, and socioeconomic and welfare determinants were essential to explain the transition from high to low levels of infant mortality. Palloni and Pinto-Aguirre (2011) studied the evolution of mortality in Latin America in the twentieth century, they showed an improvement of life expectancy levels over the last half of the twentieth century as well as a change in the causes of death, changing from infectious diseases to chronic diseases, with a prevalence of external causes in some countries. The work represents a major upgrade from previous studies on Latin America (Arriaga, 1968; 1984; Arriaga and Davis, 1969), but it opens an important path for studies of the evolution of mortality within countries. Especially the case of Brazil, marked by large socioeconomic and regional differences. 
The literature suggests a number of explanations for the advancement of mortality and improving health conditions in developed and developing countries (Cutler, et.al, 2006; Smith, 2007; Soares, 2007a; Palloni and Pinto, 2011). The process of falling mortality and increased longevity are associated with a change in the profile of the leading causes of death and mortality structure, a phenomenon known as epidemiological transition (Omran, 1971; Wilmoth, 2000; Horiuchi, 1997; Silver, 1992). However, the pace of change in the mortality pattern in the region is very heterogeneous (Palloni and Pinto, 2011) and probably also observed greater heterogeneity within each country (Castro and Simões, 2009; Souza, et. al., 2010; Queiroz and Lima, 2011; Lima and Queiroz, 2014).

\section{Mortality decline in Brazil, past and future prospects of analysis}

Like many Latin American countries, in Brazil, the mortality rates declined rapidly during a period of 60 years, reducing from 18 death per 1000 individuals in 1940 to $6 / 1000$ in 2010 . The trigger to this rapid improvement in mortality was the sharp decline in infant mortality. During that same period of time, the infant mortality rate in Brazil was estimated at 150 per thousand live births reaching 16 in 2010. In the same fashion, between 1940 and 2010, life expectancy at birth for both sexes also increased, going from 41.53 years to 73.86 years (IBGE, 2017a, 2017b). After the 1980s, another shift in the age pattern of mortality is found, characterized by a substantive decline in mortality rates among the elderly (60 or older), especially among those at oldest ages (Campos and Rodrigues, 2004).

Followed by this rapid mortality transition from high to low levels of deaths, the country has also experienced an epidemiological transition. However, this last process has not followed the same pattern as shown in most industrialized countries and as other countries in Latin America countries such as Chile, Cuba and Costa Roca (Prata, 1992; Schramm et al., 2004). The empirical evidences show that there is an overlap in health transition states, by the persistence of infectious diseases (e.g. dengue, cholera, malaria, etc.) in parallel with the increase of chronical and degenerative diseases. Hence, there is no linear path throughout every stage of the epidemiological transition, leaving it in the counter transition state (Schramm et al., 2004; Frenk et al., 1991). Moreover, both groups of morbi-mortality are also still at high levels, characterizing as a long standing transition process. Nevertheless, there are contrasting epidemiological situations across different 
regions of the country, also creating a scenario of epidemiological polarization (Schramm et al., 2004; Frenk et al., 1991). In terms of studies, Soares (2007b) analyzed the causes and the consequences of mortality reduction (focusing on the life expectancy at birth) in Brazil, allowing an advance and better understanding of the transition from high to low mortality levels in the country. According to him, that has been a number of improvements, between 1970 to 2000, which seem to be important determinants of changes in life expectancy and they were not directly correlated with income. Soares (2007b) highlights the role of increasing education, access to water and sanitation as important factors behind Brazilian mortality decline.

Moreover, studies on infant and child mortality are more established in Brazil and in other developing countries (see e.g. Alves and Beluzzo, 2004; Castro and Simões, 2009; Sousa, et.al, 2010) for several reasons. First, because there are more research on infant mortality due to the availability of data (via household surveys and censuses) and, second, due to the major methodological advances in methods to estimate child mortality. In common, these studies have also produced infant mortality estimates that helped to understand the determinants of mortality decline in Brazil over the last decades. However, there is an increase demand for more studies related to adult mortality evolution and its determinants in Brazil, as also the burden of external causes of death, which usually affect adult population, is increasing across the country (e.g. the rate reached 25 per 100,000 in the nineties, compared to a rate of 5 for 100 thousand in 1975).

Other increasing demand is related to studies of small areas mortality developments in the country. To our knowledge, one of the few studies that seek to estimate mortality levels for small areas in Brazil was done by Horta, et al. (1998). They have estimated mortality levels using indirect techniques and model life tables, and they have produced estimates of life expectancy for Brazilian cities between 1970 and 2000. However, there are a number of limitations in their estimates due to the assumptions taken in the models, the little use of available adult mortality data and the lack of specific statistical methods usually applied to small areas. Despite, this work is very important, because it was a first major empirical effort to produce estimates for small areas in Brazil.

In recent years there was breakthrough in the production of fertility estimates in small areas of Brazil. In several works of Potter and colleagues (Potter, et.al, 2010; Potter, et.al, 
2002; Assunção, et.al, 2005) fertility rates were produced for Brazilian small areas $^{2}$, using Bayesian statistical methods, which allowed them study fertility trends in small territorial entities from 1960 to 2000 . These estimates also gave a better understanding of the evolution and determinants of Brazilian Fertility Transition during the period. In the case of mortality studies, some studies have tried to estimate mortality functions and construct life tables for Brazilian municipalities based on the application of Bayesian, parametric and non-parametric models (see e.g. Queiroz et al., 2013; Lima et al. 2016; Gonzaga and Schmertmann, 2016). Nevertheless, in common, all these studies have only aimed to estimate mortality in less populated locations, and not many substantive analysis on the evolution and the causes and the determinants of mortality in small areas have been performed. Thus, this is the main focus of this study, to conduct an analytical analyses on adult mortality in 137 mesoregions of Brazil.

The determinants of mortality can be aggregated in two large groups, macro and micro ones. Micro determinants involve the characteristics of individuals and their health behavior. In addition, micro factors can influence macro level factors because they are directed related to the composition of the population in each area, such as the age composition of the population and the educational distribution of the population in each area. Changes in mortality levels across regions can be explained by macro level factors - health services, regional trends in health factors, institutional factors - and micro level factors - individual behavior, income level, educational level (cite), and the combination of macro and micro factors can feedback each other.

In a recent study, Kulkarni, et al. (2011) argue about the importance of regional mortality and health studies as guide points for the planning of public health policies and coverage of the health system. In their analysis, based on recent data from the United States, the authors show that there is a huge variability in life expectancy between locations, with some presenting mortality rates much higher than those observed in other developed countries. Similar research by Kibele, et al. (2015), in Germany, shows that the factors that explain mortality variation in the past are still affecting present regional mortality variation in the country. We can also argue that small areas in Brazil are, as the United States and Germany, characterized by mortality differences for many reasons, and also there is an increasing demand for appropriate health policies, given the current aging

\footnotetext{
2 These are Minimum Comparable Areas and microregions, usually formed by aggregation of
} municipalities. 
process of the Brazilian population. Thus, it is important to develop researches that seek to understand the evolution of mortality, its determinants and variation over the recent years.

In our analyses, we will try to analyze $45 \mathrm{q} 15$ evolution in terms of variation in socioeconomic factors, infra-structure conditions and regional health policies, as well as the spatial variation in access to infrastructure such as housing and health and emergency care, economic conditions.

\section{Methodology and Data}

Death Counts and Population Data

We make use of the Ministry of Health database, DATASUS (http://www2.datasus.gov.br). The database provides information on deaths, causes of deaths, by age and sex at the municipality level. The data are available since 1979, but we use information from 1980 to 2010 , because mesoregion was a geographical entity created by the IBGE since 1980 . Mortality data is organized using codes from the ICD Revision (9th from 1980 to 1995 and 10th from 1996 on). Data cleaning and compilation is done at the municipal, provincial and state level, and an electronic data file is transferred to the national office every 3 months. Population by age and sex, at the local level, comes from the Brazilian Censuses (1980, 1991, 2000 and 2010).

The original data is available at the municipality level. The main limitation in using city level data in Brazil is that the number and composition of cities change over time. In 1980, there were 3974 municipalities and in 2010 there were 5565. To keep geographic comparison and to avoid problems using this information, we aggregated municipalities in comparable small areas, using the IBGE definition of mesoregions. The mesoregions serve only for statistical purpose; therefore, they do not represent a political or administrative entity. The main advantage of working with these geographical areas is that they have not changed their boundaries over the period of analysis and they are areas with regional and socioeconomic similarities. Mesoregions are stable and comparable over the period of analysis. By doing this, we are able to follow and study 137 small areas in Brazil from 1980 to 2010.

\section{$\underline{\text { Adult Mortality Estimates }}$}


In a recent paper, Queiroz, et.al (2016) $)^{3}$ estimated mortality levels for mesoregions in Brazil from 1980 to 2010. The paper uses three-step procedure to estimate mortality in small areas when data is defective. First, we apply a standardization technique to smooth rates in small areas, using the mortality functions of Brazilian Federal units as benchmark of adjustment to each mesoregion inside the States. Second, we obtained measures of completeness of death counts coverage through the Death Distribution Methods. Finally, we perform a bottom-up adjustment to make sure that adding up death counts at the local level we obtain the total number of deaths in each State and the country.

We briefly review the methodology to estimate death counts coverage and adjust death counts when necessary. The proposed method is easily replicable for different contexts. We proposed a combination of standard demographic methods (Death Distribution Methods) with indirect standardization to estimate mortality levels by sex in mesoregions in Brazil. First, we standardize mortality rates from mesoregions (smaller areas), by sex, using state level data as standards. Then, we estimate the completeness of deaths counts coverage in each mesoregion. Several methods based on equations of population dynamics have been developed to evaluate the coverage of reported deaths relative to the population. The death distribution methods (DDM) are commonly used to estimate adult mortality in a non-stable population (Timeaus, 1991; Hill et al, 2005). There are three major approaches: the General Growth Balance (GGB) Methods (Hill, 1987), the Synthetic Extinct Generation (SEG) method (Benneth \& Horiuchi, 1981), the Adjusted Synthetic Extinct Generation (SEG-adj) method (Hill, You \& Choi, 2009). The death distribution methods make four strong assumptions: the population is closed to migration, the completeness of the recording of deaths is constant by age, the completeness of recording of the population is constant by age, and the ages of the living and the dead are reported without error.

\footnotetext{
${ }^{3}$ Work in progress by the same authors. The paper is in final preparation to be submitted to a scientific journal. It is part of a larger research project on estimating mortality in small-areas in Brazil funded by CNPq. Results, data and codes are available upon request. A web-site will be released whenever the paper is accepted to publication. Two working papers were presented at conferences: 1) Souza, F.H ; FREIRE, F. H. M. A. ; QUEIROZ, BERNARDO L ; LIMA, E. E. C. de ; GONZAGA, MARCOS R . Tabelas de sobrevivência para os municípios brasileiros em 2010: análise espacial do padrão e nível da mortalidade. In: XIX Encontro Nacional de Estudos Populacionais, 2014, São Pedro. Anais do XIX Encontro Nacional de Estudos Populacionais, 2014; 2) FREIRE, F. H. M. A.; QUEIROZ, B. L. ; LIMA, E. E. C. de ; GONZAGA, M. R ; Souza, F.H . Mortality Estimates and Construction of Life Tables for Small Areas in Brazil, 2010.. In: Population Association of America. 2015 Annual Meeting, 2015, San Diego-EUA. 2015 Annual Meeting, 2015
} 
Methods of Analysis

The mortality indicator used is the intercensal adult probability of death (deaths between 15 to 59 years old or 45q15) for each period of analysis. The reason for using intercensal estimates lays in the fact that the demographic methods, used to analyze and to correct the quality of death counts, are based on non-stable population models, therefore, they are derived by intercensal rates. We combine a variety of analyses to investigate the evolution and determinants of regional adult mortality differentials in Brazil.

In the first step, we use Spatial Analysis, more specifically Kernel Spatial Density to find densities of adult mortality across regions in Brazil for each period of analysis. This is preliminary descriptive analysis to get a hold on the spatial distribution of adult mortality and identify hotspots of $45 \mathrm{q} 15$ throughout time. In the second step, we use simultaneous auto-regression models (SAR) to investigate how explanatory variables (Box 1) are related to our dependent variable, e.g. intercensal 45q15, by two sort of analyses. Thus, we are first interested in analyze the correlation between dependent and independent variables for each period and on variations of $45 \mathrm{q} 15$ and each indicators. The simultaneous autoregressive model is the standard model to analyze data with spatial correlation.

We argue that adult mortality in Brazil is clustered around some areas and one should take this into account (Roux, et.al, 2007; Anselin, 2013). One advantage of the method is the dependent variable observed in one mesoregion is jointly determined with that of its neighbors. Thus, we perform the analyses in terms of two spatially dependent specifications, namely "spatial lagged" and "spatial correlated errors" (Anselin, 1988). The first assumes that the values of $y$ in one geographic unit $i$ are directly influenced by the values of $y$ found in $i$ 's neighbors. It is important to mention that, this influence is above and beyond other covariates specific to $i$. However, when $y$ is not influenced directly by the value of $y$ of its neighbors, but rather that there is some spatially clustered feature (not specified in the model) that influences the value of $y$ for $i$ and its neighbors, we applied as alternative a spatial correlated error model (Ward and Gleditsch, 2007). In order to decide the spatial specification to be used, first we applied a Lagrange multiplier diagnostics test of spatial dependence, namely lagged or error correlated $y$.

Box 1 - List of Explanatory Variables 


\begin{tabular}{|c|c|c|}
\hline Variable & Description & Expected Sign \\
\hline $45 q 15$ & $\begin{array}{l}\text { Intercensal probability of death } \\
\text { from age } 15 \text { to } 60 . \text { For the } \\
\text { censuses periods of } 1980-1991 \text {, } \\
1991-2000 \text { and } 2000-2010 \text {. }\end{array}$ & Dependent Variable \\
\hline Schooling & $\begin{array}{l}\text { Percentage of residents with } 8 \\
\text { and more years of schooling in } \\
1991,2000 \text { and } 2010\end{array}$ & $\begin{array}{l}\text { Inverse relation to mortality } \\
\text { levels. More education, lower } \\
\text { mortality }\end{array}$ \\
\hline Literacy rate & $\begin{array}{l}\text { Percentage of illiterates in the } \\
\text { population in } 1991,2000 \text { and } \\
2010\end{array}$ & $\begin{array}{l}\text { Inverse relation. Similar to } \\
\text { education. }\end{array}$ \\
\hline Poverty rate & $\begin{array}{l}\text { Percentage of individual with } \\
\text { less than } 1 / 2 \text { minimum wage } \\
\text { income in } 1991,2000 \text { and } 2010\end{array}$ & $\begin{array}{l}\text { Positive relation, higher poverty } \\
\text { rates higher mortality levels. }\end{array}$ \\
\hline Household income & $\begin{array}{l}\text { Household income level in } 1991 \text {, } \\
2000 \text { and } 2010\end{array}$ & Negative (inverse) relation. \\
\hline Gini & $\begin{array}{l}\text { Gini index as a measure of } \\
\text { income distribution and relative } \\
\text { poverty }\end{array}$ & $\begin{array}{l}\text { Positive relation, higher } \\
\text { inequality higher mortality }\end{array}$ \\
\hline Hospitalization & $\begin{array}{l}\text { Average value of hospital costs } \\
\text { per procedure in } 1992,2000 \text { and } \\
2007\end{array}$ & $\begin{array}{l}\text { Inverse relation. Indicates public } \\
\text { health measures. }\end{array}$ \\
\hline Garbage & $\begin{array}{l}\text { Percentage of household with } \\
\text { Garbage collection at the local } \\
\text { level in } 1991,2000 \text { and } 2010\end{array}$ & $\begin{array}{l}\text { Inverse relation. Indicates public } \\
\text { health measures. }\end{array}$ \\
\hline Sewage & $\begin{array}{l}\text { Percentage of households with } \\
\text { proper sewage in 1991, } 2000 \text { and } \\
2010\end{array}$ & $\begin{array}{l}\text { Inverse relation. Indicates public } \\
\text { health measures. }\end{array}$ \\
\hline Youth Population & $\begin{array}{l}\text { Ratio of individuals aged } 20 \text { to } \\
39 \text { in each local area in } 1991 \text {, } \\
2000 \text { and } 2010\end{array}$ & $\begin{array}{l}\text { Positive relation. Higher } \\
\text { external rates of mortality. }\end{array}$ \\
\hline $\begin{array}{c}\text { Population size (degree of } \\
\text { urbanization) }\end{array}$ & $\begin{array}{l}\text { The population size of each } \\
\text { mesoregion in } 1991,2000 \text { and } \\
2010 \text {, as sort of urbanization } \\
\text { degree }\end{array}$ & $\begin{array}{l}\text { Concentration might be positive } \\
\text { related to mortality levels. }\end{array}$ \\
\hline Unemployment rate & $\begin{array}{l}\text { Percentage of people without a } \\
\text { job and looking for a job in the } \\
\text { reference week in } 1991,2000 \\
\text { and } 2010\end{array}$ & $\begin{array}{l}\text { Positive relation. Higher } \\
\text { unemployment related to higher } \\
\text { mortality. }\end{array}$ \\
\hline $\begin{array}{l}\text { Longitude and Latitude } \\
\text { coordinates }\end{array}$ & Spatial control variables & $\begin{array}{l}\text { Spatial variables. Local levels of } \\
\text { mortality. }\end{array}$ \\
\hline Regional control variables & $\begin{array}{l}\text { Dummies for regions and local } \\
\text { areas }\end{array}$ & Captures unobserved variables. \\
\hline
\end{tabular}

From this list of variables, we have performed correlation and variation inflation factor

(VIF) tests as means to select the most reliable information and to avoid collinearity in posterior the regression analysis.

\section{Results}

Spatial distribution of $45 q 15$ 
Figure 1 shows Kernel Density maps for males probabilities of death between ages 15 and 60 (45q15), and Figure 2 shows the same information for females. Male adult mortality is higher than female in all regions and over the period of analysis. On average, $45 \mathrm{q} 15$ for males was 0.25 in 1980 and decline to 0.20 in 2010 , for females we find that 45q15 was about 0.15 in 1980 and decline to 0.10 in 2010. In 2010, highest levels of adult mortality for males as well as females in mesoregions are located in the Southeastern and the Coastal areas of the Northeast. In certain mesoregions of these areas, we can find 45 q15 ranging from levels of 40 to $50 \%$ in 1980 and 25 to $45 \%$ in 2010, among males. For women, these levels were somewhat lower from 20 to $30 \%$ in 1980 and from 15 to $20 \%$ in 2010 . Despite the overall decline of adult mortality levels throughout time, we also noticed that there is an evolution to homogenization and convergence of $45 \mathrm{q} 15$ across the country. In other words, even with the persistence of hotspots in certain locations of Brazil, adult mortality levels are becoming more alike across mesoregions. This widespread phenomena is more pronounced among females.

Figure 1- Kernel Density, Intercensal Adult Probabilities of Death, Males, Brazil, 1980-2010.

Kernel Density, Intercensal adult probability of Death. Kernel Density, Intercensal adult probability of Death. Kernel Density, Intercensal adult probability of Death Brazil, Men, Mesorregions in 1980-1991. Brazil, Men, Mesorregions in 1991-2000. Brazil, Men, Mesorregions in 2000-2010.
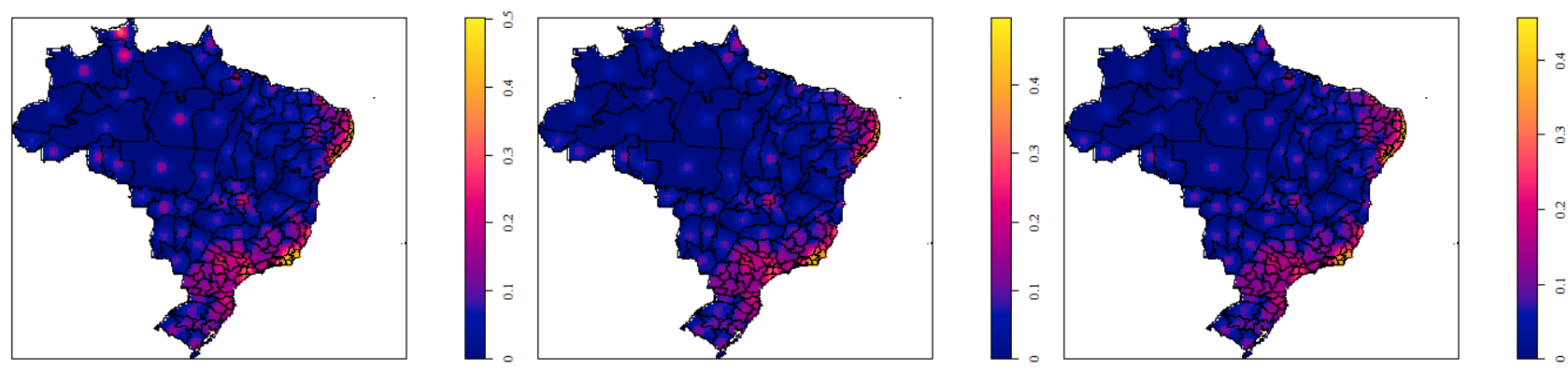

Figure 2- Kernel Density, Intercensal Adult Probabilities of Death, Females, Brazil, 1980-2010.

Kernel Density, Intercensal adult probability of Death. Kernel Density, Intercensal adult probability of Death. Kernel Density, Intercensal adult probability of Death Brazil, Women, Mesorregions in 1980-1991. Brazil, Women, Mesorregions in 1991-2000. Brazil, Women, Mesorregions in 2000-2010
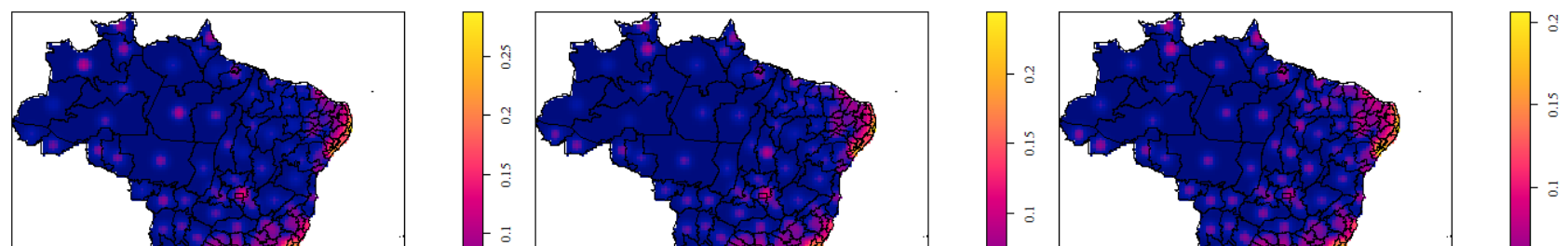
Source: DATASUS and Brazilian censuses 1980 to 2010.

\section{Simultaneous Autoregression - cross-sectional analyses}

We now focus our analysis on the regression models. We are interested in the relationship between explanatory variables and the levels of adult mortality in each mesoregion of the country, therefore, we run separate models for each year and models considering the variation in intercensal adult mortality, between 1980-1991 and 2000$2010^{4}$. Table 1 shows results for males and Table 2 shows results for females.

The results indicate interesting results about the association between adult mortality and socioeconomic factors in Brazil. For males, we find that in all periods of analysis higher level of unemployment is related to higher probabilities of death in the country, even if this effect is becoming less strong throughout time. Higher unemployment rates are related to slow economic growth and development, lower income and worse institutional aspects (Irons, 2009). This can also be seen through the Gini index. An increment in Gini, i.e. increasing income inequality, is strongly associated with increase probability of dying in 1980-1991. We can argue that in this first period, income inequality was still at high levels in the country and that might have also influenced the levels of adult mortality. However, in the coming periods this income distribution index lost statistical significance, and a plausible explanation is related to the fact that inequality in the country has been strongly reduced since the 1980s (World Bank, 2016).

Table 1 - Simultaneous Autoregressive Models (SAR) of $45 \mathrm{q} 15$ for Males, according to different spatial dependence specifications. Brazil, 1980 - 2010.

Type of spatial dependency and period

\footnotetext{
${ }^{4}$ We have also performed some tests using pooled data, due to paper extension these results are not showed here.
} 


\begin{tabular}{|c|c|c|c|c|c|c|}
\hline \multirow{3}{*}{$\begin{array}{c}\text { SAR models of intercensal adult mortality for the periods } \\
1980-1991,1991-2000 \text { and } 2000-2010 . \\
\text { Control Variables }\end{array}$} & \multirow{2}{*}{\multicolumn{2}{|c|}{$\begin{array}{c}\text { Lag } \\
1980-1991 \\
\end{array}$}} & \multirow{2}{*}{\multicolumn{2}{|c|}{$\begin{array}{c}\text { Error } \\
1991-2000 \\
\end{array}$}} & \multirow{2}{*}{\multicolumn{2}{|c|}{$\frac{\text { Lag }}{2000-2010}$}} \\
\hline & & & & & & \\
\hline & Estimate & Sig & Estimate & Sig & Estimate & Sig \\
\hline (Intercept) & -0.394 & $* * *$ & -0.063 & & -0.013 & \\
\hline \multicolumn{7}{|l|}{ Socioeconomic variables } \\
\hline Percentage of men with more than 8 years of school & -0.001 & $*$ & 0.000 & & 0.001 & $* *$ \\
\hline Gini & 0.203 & $* *$ & -0.052 & & 0.036 & \\
\hline $\begin{array}{l}\text { Unemployment rates } \\
\text { Population size of mesoregion in } 10^{5} \text { (degree of } \\
\text { urbanization) }\end{array}$ & $\begin{array}{l}0.008 \\
0.000\end{array}$ & $* * *$ & $\begin{array}{l}0.004 \\
0.000\end{array}$ & $* * *$ & $\begin{array}{l}0.002 \\
0.000\end{array}$ & $*$ \\
\hline \multicolumn{7}{|l|}{ Medical variables } \\
\hline \multicolumn{6}{|l|}{ Sanitation variables } & \\
\hline \multicolumn{6}{|l|}{ Demographic Variables } & \\
\hline \multicolumn{6}{|l|}{ Spatial Variables } & $* *$ \\
\hline Longitude coordinate & -0.001 & & 0.001 & & 0.001 & $* *$ \\
\hline Latitude coordinate & 0.001 & & -0.002 & & -0.001 & $* *$ \\
\hline \multicolumn{7}{|l|}{ Ref. Southeastern region } \\
\hline Northern region & -0.031 & & 0.006 & & 0.023 & $*$ \\
\hline Northeastern region & 0.005 & & -0.018 & & 0.007 & \\
\hline Southern region & -0.025 & & -0.014 & & -0.002 & \\
\hline Mid-Western region & -0.037 & $* *$ & -0.010 & & 0.004 & \\
\hline $\begin{array}{l}\text { Dependency parameter and percentage of explained } \\
\text { variance }\end{array}$ & $\begin{array}{r}\text { Rho }=0.3 \\
\mathrm{R}^{2}=0.71\end{array}$ & & $\begin{array}{r}\text { Lambda } \\
\mathrm{R}^{2}=0 .\end{array}$ & $\begin{array}{l}=0.59 \\
59\end{array}$ & $\begin{array}{r}\text { Rho }=0.4 \\
\mathrm{R}^{2}=0.33\end{array}$ & \\
\hline
\end{tabular}

We also find that, controlling for other factors, in 1980-1991 concentration of educated men in the area reduced male adult mortality. The effect is small and changed signs in 2000 and 2010. Finally, we observed that the concentration of young adults in the area is related to higher levels of adult mortality. This population segment is known to be more prone to risks of dying to external causes of death, which are still presenting quite higher levels in the country. For example, in 2012, $79.2 \%$ of male deaths and $38.5 \%$ of female deaths occurred due external causes (Neves and Garcia, 2015). High levels of income inequality is also associated with more adult mortality. Table 2 shows the results for females. The results are very similar to what is observed for males. Higher unemployment rates are associated with higher adult mortality for females. Concentration of young adults is also related to higher probabilities of deaths for females. Other set of variables, medical and sanitary ones, do not present relationship with the $45 q 15$ in any period considered. 
Table 2 - Simultaneous Autoregressive Models (SAR) of 45q15 for Females, according to different spatial dependence specifications. Brazil, 1980-2010.

\begin{tabular}{|c|c|c|c|c|c|}
\hline \multirow{3}{*}{$\begin{array}{l}\text { SAR models of intercensal adult mortality for the periods } \\
\qquad 1980-1991,1991-2000 \text { and } 2000-2010 \text {. }\end{array}$} & \multicolumn{5}{|c|}{ Type of spatial dependency and period } \\
\hline & \multicolumn{2}{|l|}{ Lag } & \multicolumn{2}{|l|}{ Lag } & Lag \\
\hline & \multicolumn{2}{|l|}{$1980-1991$} & \multicolumn{2}{|c|}{$1991-2000$} & $2000-2010$ \\
\hline Control Variables & Estimate & Sig & Estimate & Sig & Estimate Sig \\
\hline (Intercept) & -0.130 & $* *$ & 0.006 & & 0.021 \\
\hline \multicolumn{6}{|l|}{ Socioeconomic variables } \\
\hline Percentage of women with more than 8 years of school & -0.002 & $* *$ & 0.000 & & 0.000 \\
\hline Gini & 0.137 & $* *$ & 0.013 & & 0.052 \\
\hline $\begin{array}{l}\text { Unemployment rates } \\
\text { Population size of mesoregion in } 10^{5} \text { (degree of } \\
\text { urbanization) }\end{array}$ & $\begin{array}{l}0.002 \\
0.000\end{array}$ & & 0.001 & & $\begin{array}{l}0.000 \\
0.000\end{array}$ \\
\hline \multicolumn{6}{|l|}{ Medical variables } \\
\hline \multicolumn{6}{|l|}{ Sanitation variables } \\
\hline $\begin{array}{l}\text { Percentage of household with sewage system } \\
\text { Demographic Variables }\end{array}$ & 0.000 & & 0.000 & & 0.000 \\
\hline $\begin{array}{l}\text { Percentage of Population between ages } 20 \text { to } 39 \text { years old } \\
\text { Spatial Variables }\end{array}$ & 0.012 & $* * *$ & 0.004 & $* *$ & 0.000 \\
\hline Longitude coordinate & 0.000 & & 0.001 & & 0.000 \\
\hline Latitude coordinate & 0.000 & & -0.001 & $* *$ & $-0.001 *$ \\
\hline \multicolumn{6}{|l|}{ Ref. Southeastern region } \\
\hline Northern region & 0.013 & & 0.016 & & 0.008 \\
\hline Northeastern region & -0.008 & & -0.002 & & 0.003 \\
\hline Southern region & -0.007 & & -0.009 & & -0.006 \\
\hline Mid-Western region & -0.003 & & -0.004 & & -0.002 \\
\hline $\begin{array}{l}\text { Dependency parameter and percentage of explained } \\
\text { variance }\end{array}$ & $\begin{array}{c}\text { Rho }=0.31 \\
\mathrm{R}^{2}=0.42\end{array}$ & & $\begin{array}{r}\text { Rho }=0.2 \\
\mathrm{R}^{2}=0.39\end{array}$ & & $\begin{array}{l}\text { Rho }=0.30 \\
\mathrm{R}^{2}=0.12\end{array}$ \\
\hline
\end{tabular}

$\mathrm{p}<0.001^{* * *}, \mathrm{p}<0.05^{* *}$ and $\mathrm{p}<0.10 *$

Source: DATASUS and Brazilian censuses 1980 to 2010.

In common, we see that all models are showing a reducing evolution of percentage of explained variance by the covariates as time passing. This might indicate that socioeconomic differences lost prediction power and other unobserved variables may be associated with the levels of adult mortality in the most recent periods. This finding is consistent with the spatial dependency parameter Rho, which is increased among males as well as females. Regarding spatial dependence, we see that (with exception of 19912000 males) lagged models are the most appropriated to apply, in other words the $45 q 15$ of a random unit $i$ is directly influenced by the adult mortality of its neighbors. This means 
that there are some unobserved communitarian relationships among mesoregions that explains variability in levels of mortality between ages 15 to 60 .

Other interesting feature is the spatial distribution of $45 \mathrm{q} 15$ in the last period of analysis (2000-2010). The latitude (negative sign) and longitude (positive sign) coordinates for males are suggesting that moving to Southern and Coastal areas of the country the probability of die between ages 15 to 60 years are higher. Among females, we find only statistical significance with the latitude coordinates, which indicates direction throughout South and Southeastern parts of the country. The result might also indicate the advanced spatial convergence and homogenization process of adult mortality among women, as we saw in the Figure 2.

\section{Simultaneous Autoregression - Variation in 45 q15 from 1980 to 2010.}

In the second part of the regression analysis, we are interested in looking at variations in adult mortality $(45 \mathrm{q} 15)$ and its variations in the explanatory variables. That is for each variable, we have estimated differences between values of the last against first period. In this case, we are interested in looking at how improvements or worsening in conditions in each mesoregion are related to the changes in the observed level of adult probabilities of deaths. Tables 3 shows the results for females and males, respectively. In this case, we also use an autoregressive regression model. One interesting result is that the increasing percentage in the percentage of young adult population is related to an increase in $45 \mathrm{q} 15$ for both males and females. This relationships is even three times stronger among males. We also find that, for females, decrease in unemployment rates from $1980 / 1991$ to $2000 / 2010$ is related to an increase in the $45 q 15$. This is an unexpected result and more analyses need to be performed in order to understand this association. Gini Index, a measure of income inequality, has also an impact on the observed changes in 45q15, but only among males. More intriguing, the relationship has change signal during the period of analysis, indicating that improvements in income distribution (decline in gini) are associated with more deaths between ages 15 to 60 years. We can speculate that actual changes in relative poverty came together with increasing in violence across the country, therefore, increased the risks of deaths due to external causes, which is common among adult males. Once more, spatial heterogeneity of $45 q 15$ is greater among males than females, and looking only at the spatial coordinates we see that 
Southern-Southeastern and Coastal locations of the country have increased as hotspots of adult mortality, although, among females there is no statistical significance related to spatial location of the mesoregion, reinforcing the idea of evolution to spatial homogeneity of adult mortality levels.

Table 3: Variation from year to year: autoregressive spatial regression, Males, 1980-

2010

\begin{tabular}{|c|c|c|c|c|}
\hline \multirow{2}{*}{$\begin{array}{l}\text { Lag spatial dependence model, variation in } 45 q 15 \text { from } 1980 / 1991 \text { to } 2000 / 2010 \\
\text { Variables }\end{array}$} & \multicolumn{2}{|l|}{ Females } & \multicolumn{2}{|l|}{ Males } \\
\hline & Estimate & Sig & Estimate & Sig \\
\hline (Intercept) & -0.031 & & -0.041 & \\
\hline \multicolumn{5}{|l|}{ Socioeconomic variables } \\
\hline Variation in percentage of years of education & 0.000 & & 0.001 & \\
\hline Variation in Gini & -0.107 & & -0.207 & * \\
\hline Variation in unemployment rates & -0.004 & ** & -0.001 & \\
\hline Variation in population size of mesoregion in $10^{5}$ & 0.000 & & 0.000 & \\
\hline \multicolumn{5}{|l|}{ Medical variables } \\
\hline Variation in value expended in hospitalization, $1992-2010$ & 0.000 & & 0.000 & \\
\hline \multicolumn{5}{|l|}{ Sanitation variables } \\
\hline Variation in percentage of household with sewage system & 0.000 & * & 0.000 & \\
\hline \multicolumn{5}{|l|}{ Demographic Variables } \\
\hline Variation in percentage of population between ages 20 to 39 years old & 0.009 & $* *$ & 0.027 & $* * *$ \\
\hline \multicolumn{5}{|l|}{ Spatial Variables } \\
\hline Longitude coordinate & 0.000 & & 0.002 & $*$ \\
\hline Latitude coordinate & 0.000 & & -0.003 & $* *$ \\
\hline \multicolumn{5}{|l|}{ Ref. Southeastern region } \\
\hline Northern region & -0.016 & & 0.024 & \\
\hline Northeastern region & 0.018 & & 0.007 & \\
\hline Southern region & 0.001 & & 0.021 & $*$ \\
\hline Mid-Western region & -0.010 & & 0.014 & \\
\hline Dependency parameter and percentage of explained variance & $\begin{array}{l}\text { Rho }=0.23 \\
\mathrm{R}^{2}=0.35\end{array}$ & & $\begin{array}{r}\text { Rho }=0.2 \\
\mathrm{R}^{2}=0.63\end{array}$ & \\
\hline
\end{tabular}

\section{Conclusion and discussion}

In this paper, we investigate the spatial and temporal evolution of adult mortality by sex, across regions in Brazil. In recent years, there were several studies focusing on 
infant and child mortality and the determinants of observed changes. There are very few studies on adult mortality and we believe that significant changes in life expectancy and future trends in mortality are going to be driven by changes in adult mortality.

The main result of the paper is the convergence of adult mortality across regions of the country between 1980 and 2010. There are still significant differences across regions and we are able to identify hotspots of high levels of adult mortality in some areas of the countries. These areas are very related to an increase of mortality for external causes affecting young males (Waiselfisz, 2013; Pereira and Queiroz, 2016). Reduction in the mortality levels in areas with lower socioeconomic levels might imply better living conditions and overall improvements.

The second interesting result is the decline in the effect of socioeconomic variables in reducing mortality levels in the country. More interesting, we observe that for some regions of the countries a reduction in inequality levels is closely related to an increase in adult mortality. We should analyze that with caution since we might be observing less explanatory power from our variables because of unobserved factors. We should try different model specifications in order to test this relation.

In the next step of the paper, we aim to work with smaller areas of analysis and to include some additional discussion on the trends in causes of deaths, focusing on external causes and cardiovascular diseases. This is important because we did not find a significative reduction in the male-female mortality differential across regions and time, and trends in causes of deaths might be the main explanation for that.

\section{References}

Alves, D. e Beluzzo, W. Infant mortality and child health in Brazil. Economics and Human Biology, v2, n3 (December), 2004: 391-410.

Anselin, Luc. Spatial econometrics: methods and models. Vol. 4. Springer Science \& Business Media, 2013.

Arriaga, E. E. \& Davis, K., 1969. The pattern of mortality change in Latin America. Demography, 6: 223-242.

Assunção, R. M.; Schmertmann, C. P.; Potter, J. E.; Cavenaghi, S. M. (2005).Empirical Bayes Estimation of Demographic Schedules for Small Areas. Demography, Vol. 42, No. 3, (Aug., 2005), pp. 537-558. 
Barufi, Ana Maria, Eduardo Haddad, and Antonio Paez. "Infant mortality in Brazil, 19802000: A spatial panel data analysis." BMC public health 12, no. 1 (2012): 1.

Castro, M.C; Simoes, C.C.S. (2009). Spatio-Temporal Trends of Infant Mortality inBrazil. Paper presented at the XXVI IUSSP International Population Conference, Marocco.

Cutler, David, Angus Deaton, and Adriana Lleras-Muney. "The determinants of mortality." The Journal of Economic Perspectives 20, no. 3 (2006): 97-120.

Dorrington R.E. General Growth Balance. In Moultrie TA, RE Dorrington, AG Hill, KH Hill, IM Timæus and B Zaba (eds), Tools for Demographic Estimation. http://demographicestimation.iussp.org/content/general-growth-balance,

2011.Accessado em 25/07/2012

Dorrington R.E. Synthetic extinct generations. In Moultrie TA, RE Dorrington, AG Hill, KH Hill, IM Timæus and B Zaba (eds), Tools for Demographic Estimation. http://demographicestimation.iussp.org/content/synthetic-extinct-generations, 2011 Accessado 25/07/2012

Dorrington, R e Timaeus, I. Death Distribution Methods for Estimating Adult Mortality: Sensitivity Analysis with Simulated Data Errors, Revisited. Paper presented at the 2008 Annual Meeting of the Population Association of America - Nova Orleans, Estados Unidos., 2008

Ezzati, M., Friedman, A., Kulkarni, S., Murray, C. The reversal of fortunes: trends in county mortality and cross-county mortality disparities in the United States. Plos Medicine, Vol. 5, no. 4, 2008.

Fenelon, A. (2013). Geographic Divergence in Mortality in the United States. Population and Development Review, 39(4), 611-634. http://doi.org/10.1111/j.17284457.2013.00630.x

Frenk J et al. 1991. La transición epidemiológica en América Latina. Boletín de la Oficina Sanitaria Panamericana 111(6):485-496.

Hill, K.,, You, D. e Choi, Y. (2009) Death Distribution Methods for Estimating Adult Mortality: sensitivity analysis with simulated data errors Demographic Research, vol 21, 2009 .

Hill, K.; Choi Y.; Timaeus, I. Unconventional approaches to mortality estimation. Demographic Research, v.13, 2005, p.281-300.

Horta, C; Sawyer, D.; Carvalho, J. A. À Procura de Identificação dos Padrões de Mortalidade no Brasil. XV Encontro Nacional de Estudos Populacionais ABEP. Caxambu: 2006.

Horta, C. J. G., Nogueira, O. J., Rodriguez, L. e Carvalho, J.A.M. Estimativas de mortalidade para os municípios brasileiros - Uma proposta metodológica para resultados comparativos. XI Encontro Nacional de Estudos de População. ABEP, Caxambu, 1998, 2797-809. 
IBGE (2017a). Series Historicas e Estatisticas. Esperança de vida ao nascer. Access: http://seriesestatisticas.ibge.gov.br/series.aspx?vcodigo=POP210.

IBGE (2017b) Brasil em Sintese. Esperança de vida ao nascer. Access: http://brasilemsintese.ibge.gov.br/populacao/esperancas-de-vida-ao-nascer.html.

Irons, J. Economic scarring: the long-term impacts of the recession. Economic Policy Institute (Briefing paper). No 243, 2009.

Kibele Eva U. B. Regional mortality differences in Germany. Heidelberg: Springer; 2012

Kibele, Eva UB, Sebastian Klüsener, and Rembrandt D. Scholz. Regional Mortality Disparities in Germany. KZfSS Kölner Zeitschrift für Soziologie und Sozialpsychologie 67, no. 1 (2015): 241-270.

Klüsener Sebastian, Zagheni Emilio. The East-West gradient in spatial population development within Germany: Temporary GDR legacy versus longstanding spatial disparities. Historical Methods. 2014;47:167-179. doi: $10.1080 / 01615440.2014 .955234$

Kulkarni et al.: Falling behind: life expectancy in US counties from 2000 to 2007 in an international context. Population Health Metrics 2011 9:16.

Leone, Tiziana. "Measuring differential maternal mortality using census data in developing countries." Population, Space and Place, 20.7 (2014): 581-591.

Lima, E. E. C.; Queiroz, B. L.. A evolução do sub-registro de mortes e causas de óbitos mal definidas em Minas Gerais: diferenciais regionais. Revista Brasileira de Estudos de População, Rio de Janeiro, v. 28, n. 2, p. 303-320, jul./dez. 2011.

Lima, E. E. C. D., \& Queiroz, B. L. (2014). Evolution of the deaths registry system in Brazil: associations with changes in the mortality profile, under-registration of death counts, and ill-defined causes of death. Cadernos de Saúde Pública, 30(8), 1721-1730.

Lima, E. E. C. D., Queiroz, B. L., \& Sawyer, D. O. (2014). Estimating death counts completeness and mortality in small areas: an application to Minas Gerais microregions. Cadernos Saúde Coletiva, 22(4), 409-418.

Masquelier, Bruno, Georges Reniers, and Gilles Pison. "Divergences in trends in child and adult mortality in sub-Saharan Africa: survey evidence on the survival of children and siblings." Population Studies 68, no. 2 (2014): 161-177.

Macinko J, Guanais FC, de Souza MDM: Evaluation of the impact of the Family Health Program on infant mortality in Brazil, 1990-2002. Journal of Epidemiology and Community Health 2006, 60(1):13-19.

Neves, A.C.M and Garcia, L.P. Youth mortality in Brazil: profile and trends in the period 2000-2012. Epidemiologia e Serviços de Saúde. Vol. 24, No. 4, 2015.

Paes, N. A. (2005). Avaliação da cobertura dos registros de óbitos dos Estados brasileiros em2000. Revista de Saúde Pública, USP, v. 39 n.6, p. 882-90. 
Paes, N. A. (2007). Qualidade das estatísticas de óbitos por causas desconhecidas dos Estados brasileiros. Rev. SaúdePública, v. 41, n. 3, p. 436-45.

Paes, N. A.; M. E. E. (1999) Avaliação da qualidade dos dadospopulacionais e cobertura dos registros de óbitos para as regiões brasileiras. Revista de Saúde Pública, USP, v. 33, n. 1, p. 33-43.

Palloni, A. 1990, 'Health levels and care in Latin America: the case of infant mortality 1900-1985', in Caldwell, Findley et al. 1990, pp.189-212.

Palloni, A., Pinto, G.. Adult Mortality in Latin America and the Caribbean. In:Rogers, R e Crimmins, E. (eds) International Handbooks of Adult Mortality pgs -101-132, 2011.

Pereira, F., and Queiroz, B.. "Differences in mortality in Brazilian youth: the importance of household socioeconomic factors and living conditions in Brazilian municipalities and states." Cadernos de Saúde Pública 32, no. 9 (2016).

Prata, P. R. A transição epidemiológica no Brasil. Cad. Saúde Pública. 1992, vol.8, n.2, pp.168-175.

Piscoya-Diaz, M. e Queiroz, B. L.. What do we know about adult mortality and data quality in Peru? Mortality coverage levels and trends from recent decades. Papeles de Poblacion 2010, vol.16, n.63

Potter, Joseph E., Carl P. Schmertmann, and Suzana M. Cavenaghi. "Fertility and development: Evidence from Brazil." Demography 39, no. 4 (2002): 739-761.

Preston, S. H. 1976. Mortality Patterns in National Populations. New York: Academic Press.

Preston, S.H. 1980. Causes and Consequences of Mortality Declines in Less Developed Countries during the Twentieth Century. In: Easterlin 1980. Population and Economic Change in Developing Countries. Chicago: University of Chicago Press.

Queiroz, B.L., Lima, E.; Freire, F; Gonzaga, M. (2016) "Temporal and spatial estimates of adult mortality for small areas in Brazil, 1980-2010”. Working Paper in preparation to submission.

Ribeiro, E. ande Cano,I. Lethal victimization and inequalities in Brazil Evidence at a municipal level. Civitas. Vol 16, No 2. 2016.

Rodriguez-Garcia, J.. Desigualdades socioeconómicas entre departmentos y su asociación con indicadores de mortalidad en Colombia en 2000. Rev Panam Salud Publica. 2007, vol.21, n.2-3

Roux, Ana V. Diez, Tracy Green Franklin, Marcio Alazraqui, and Hugo Spinelli. "Intraurban variations in adult mortality in a large Latin American city." Journal of Urban Health 84, no. 3 (2007): 319-333. 
Sastry, N.. "Trends in Socioeconomic Inequalities in Mortality in Developing Countries: The Case of Child Survival in São Paulo, Brazil," Demography, 41(3): 443-464, $2004 \mathrm{a}$

Sastry, N. Urbanization, Development, and Under-Five Mortality Differentials by Place of Residence in São Paulo, Brazil, 1970-1991, Demographic Research, Special Collection 2: 355-386, 2004b.

Schmertmann, C., Potter, J., e Cavenaghi, S., "Exploratory Analysis of Spatial Patterns in Brazil's Fertility Transition”. Population Research and Policy Review 27(1):115. 2008.

Schramm, Joyce Mendes de Andrade et al. Transição epidemiológica e o estudo de carga de doença no Brasil. Ciênc. saúde coletiva. 2004, vol.9, n.4, pp.897-908.

Soares, Rodrigo R. On the determinants of mortality reductions in the developing world. Population and Development Review 33, no. 2 (2007a): 247-287.

Soares R., Health and the evolution of welfare across Brazilian municipalities. Journal of Development Economics, 84(2):590-608, 2007b.

Sousa, Angelica, Kenneth Hill, and Mario R. Dal Poz. Sub-national assessment of inequality trends in neonatal and child mortality in Brazil. International journal for equity in health 9, no. 1 (2010): 1.

Timaeus, I. M. Measurement of adult mortality in less developed countries: A comparative review. Population Index, v.57, n.4, p.552-568, 1991

Valkonen, T. "Trends in regional and socio-economic mortality differentials in Finland" International Journal of Health Science, 3(3-4):157-166, 1992.

Vega, A L; Torcida, S. E Velazquez, G. A. Análisis de la Evolución de la Tasa de Mortalidad Infantil en los Departamentos de Argentina: 1994-2003. Salud colectiva. 2006, vol.2, n.3

Waiselfisz, J. J. Mapa da violência 2013: Homicídios e juventude no Brasil. Instituto Sangari. São Paulo, 2013.

Wilmoth, J. Demography of Longevity: past, present and future trends. Experimental Gerontology, 2000.

Woods Robert. Urban-rural mortality differentials: An unresolved debate. Population and Development Review. 2003; 29:29-46.

Wood, C. H.; Carvalho, J. A. M. The Demography of Inequality in Brazil. Cambridge Latin American Studies, n. 67, 1988. 